IJ§ER

ISSN: 2149-5939
International Journal of Social Sciences and Education Research

Online, http://dergipark.gov.tr/ijsser

Volume: 2(3), 2016

\title{
Turkish EFL students' perceptions about blended English courses in a teacher education program
}

\author{
Hatice Yağc1 \\ Halil İbrahim Çınarbaş \\ Rabia Hoş ${ }^{1}$
}

Received Date: $08 / 01 / 2016$

Accepted Date: 31 / 03 / 2016

\begin{abstract}
The aim of this study was to investigate English Language Teaching (ELT) students' perceptions about blended learning on the improvement of language skills. The study also found out the students' opinions about the advantages and the limitations of blended learning, and gathered the suggestions for the improvement of the blended learning experience. Quantitative research methodology was used in the study. The data was collected through blended learning perceptions questionnaire. The sample consisted of 101 Turkish ELT students selected by random stratified sampling. The results showed that students mostly had positive attitudes towards blended courses and they found these courses advantageous and beneficial for improving language skills. They reported that blended learning improved their vocabulary and listening at most. The use of multimedia was thought to be one of the greatest advantages of the blended learning. The connection problem was found out to be the biggest limitation faced by the students. Finally, the participants suggested more technical support to be provided during blended courses.
\end{abstract}

Keywords: blended learning, English language teaching, student perceptions

\section{Introduction}

The increasing use of advanced technology has affected the various aspects of people's daily lives. Education is among the sectors, which is influenced by these developments. Due to the rapid changes in web-based communication and the availability of various multimedia tools, new innovative instructional methods and techniques are introduced to learners, teachers and practitioners every day (Lim, Morris, \& Kupritz, 2007).

The cooperation of advanced technologies and education started in the 1980s with the early examples of distance education in the format of audio and video teleconferences which then were transformed into internet based "virtual" classes (Moore \& Kearsley, 2012). This new style in the education provided equal educational opportunities for people living in different areas, in other words it globalized the education (Heinich, Molenda, Russell \& Smaldino, 2002).

Research questioning the effectiveness of distance learning showed that these online courses did not meet the needs of the students (Rovai \& Jordan, 2004). Abrahamson (1998) stated that distance teaching required students to be independent and self-regulated learners. The study of Marino (2000) also revealed that some students found it difficult to get used to the structure of online courses and they had trouble in managing their time, and maintaining self-motivation.

\footnotetext{
${ }^{1}$ Zirve University, Faculty of Education, English Language Teaching Dept. Correspondence: Dr. Zirve University Faculty of Education Kizilhisar Campus, Gaziantep / TURKEY 27260 Tel: 90 342-211-6666 ext. 6986. E-mail: rabia.hos@zirve.edu.tr
} 
Yağcı, H., Çınarbaş, H.İ., Hoş, R. (2016). Turkish EFL students' perceptions about blended English courses in a teacher education program. International Journal of Social Sciences and Education Research, 2 (3), 774-784.

Therefore, another term 'blended learning', which is the combination of online and face-to-face learning, has emerged in the field of education in recent years (Rooney, 2003).

There is not a single definition of 'blended learning' (Bonk \& Graham, 2006). Brew (2008) defines it as "integrating the online and face-to-face formats to create a more effective learning experience" (p. 98). Procter (2003) describes it as "the effective combination of different modes of delivery, models of teaching and styles of learning" (p. 3). According to Stewart (2002), "Blended learning is a mix of self-paced (asynchronous) work and instructor-led (synchronous or face-to-face) elements" (p. 270). In this study, Allan's (2007) description of the blended learning as "the use of different internet-based tools including chat rooms, discussion groups, podcasts and self-assessment tools to support a traditional course" (p. 4) was adopted as the most appropriate one, because it clearly states the tools that are used.

\section{Literature review}

Previous research on blended learning has investigated different aspects of it: advantages and disadvantages of blended learning (Smart \& Cappel, 2006), students' perceptions about blended learning (Delialioğlu \& Yıldırım, 2007) and effects of blended learning on improving language skills (Bueno-Alastuey \& López-Pérez, 2014).

The shift towards blended learning is an important development in education and as it is a combination of face-to-face instruction with e-learning, it bears the advantages of both. Among the many advantages of blended learning, learners' active engagement in the process of learning is favored (Sarason \& Banbury, 2004). As online learning management systems and web-based activities used in blended courses provide an interactive environment and allow for students' active involvement with the materials, it is helpful for the learners to internalize the knowledge learned in the class (Pallof \& Pratt, 2003). It also increases learner autonomy by increasing selfdirectedness and giving them a chance to take part in the decision-making process of their own learning (Osguthorpe \& Graham, 2003). Additionally, e-learning tools in a blended class create a flexible learning environment by giving the learners the freedom of studying without the time and location restrictions (Smart \& Cappel, 2006).

While harboring new opportunities both for instructors and for students, blended learning also carries some challenges (Redmond, 2011). The major drawback of the blended learning is the limited amount of social interaction (Heinze \& Procter, 2004). Although some of the courses in blended learning are face-to face, the number of hours may not be enough to socialize. The lack of face-to-face communication might cause some other problems as well. Hisham, CheSu, and Hassan Abu Bakar (2006) emphasize that if the instructions related to online tasks are not clearly provided, the learners might feel lost and have difficulties in getting used to blended learning. Furthermore, when the students face difficulties in completing online tasks, they might get frustrated, anxious and confused (Hara \& Kling, 2000). It might also be burdening for instructors as it necessitates managing two learning means and creating extra learning materials (Rogers, 2001).

In some of the studies, the students' perceptions about blended learning have been evaluated. Deghaidy and Nouby (2008) compare the blended learning with traditional classroom teaching, and concluded that the learners had higher achievement rates and had more positive attitude toward blended learning. Additionally, Kistow (2011) found out that the students enjoyed taking part in blended learning because of the flexibility provided by the online part of the courses, and 
Yağcı, H., Çınarbaş, H.İ., Hoş, R. (2016). Turkish EFL students' perceptions about blended English courses in a teacher education program. International Journal of Social Sciences and Education Research, 2 (3), 774-784.

they mentioned the importance of networking opportunities. Chen and Jones (2007) conducted another survey with Master of Business Administration (MBA) students in an accounting class in the U.S.A. to see the differences between students' attitudes towards blended and traditional classes. In the survey, there were two groups of students; one of the groups enrolled in traditional-inclass section and the other group attended blended learning classes. While the general perceptions of the classes were positive for both groups, there were some interesting results to mention. The students who participated in the traditional class were happier with the clear instructions than the students in blended learning class. On the other hand, blended learning students stated that they had a better understanding of the concepts in the field and blended learning improved their analytical skills. Therefore, the learning outcomes can differ according to the methods used but also the findings of the study by Akkoyunlu and Soylu (2008) showed that the views of the learners about blended learning could vary according to their learning styles.

Not only students' perceptions but also the effects of blended learning on improving language skills have been the interests of numerous research. Bueno-Alastuey and López-Pérez (2014) have revealed in their study that the perceptions of learners about the usefulness of e-learning in blended language classrooms differed according to the different language skills. In this study, learners engaging in online classes found blended learning more useful for receptive skills than productive skills but the learners engaging in online classes more found blended learning more useful for productive skills than receptive skills. According to Byrne (2007), blended learning is especially useful in writing while Ayres (2002), points out that including online tools in learning supports learners in developing their spelling and grammar. Moreover, Lee and Chong (2007) suggest that web-based materials have a positive impact on improving vocabulary and listening skills.

Under the light of the current literature, this study aims to investigate the perceptions of the Turkish English Language Teaching (ELT) students at a private foundation university about the advantages and disadvantages of blended learning in improving language skills, and to explore the perceived limitations and suggestions.

\section{Methodology}

Quantitative methodology (Cohen, Manion, \& Morrison, 2007) was used in this study to investigate the perceptions of Turkish ELT Students about blended English courses.

\subsection{The research questions of the study}

1. What are the perceptions of Turkish ELT students about the effects of blended learning on the development of their language skills?

2. What do Turkish ELT students think are the advantages and disadvantages of blended learning?

3. What are the suggestions of Turkish ELT students for improving the quality of blended learning?

4. Do variables such as students' grade level, age, gender, experience with blended learning, computer and Internet literacy correlate with their perceptions about blended learning? 
Yağcı, H., Çınarbaş, H.İ., Hoş, R. (2016). Turkish EFL students' perceptions about blended English courses in a teacher education program. International Journal of Social Sciences and Education Research, 2 (3), 774-784.

\subsection{Participants}

The participants in this study were 101 Turkish undergraduate ELT students enrolled at a private university in Gaziantep in 2014/2015 academic year. The participants were selected through stratified random sampling. Dörnyei (2007) finds stratified random sampling useful as it includes a random sample that is grouped proportionately according to the research purpose. Therefore, the population was divided into four strata according to the grades of the students. The participants consisted of freshman $(\mathrm{N}=30)$, sophomore $(\mathrm{N}=24)$, junior $(\mathrm{N}=23)$, and senior $(\mathrm{N}=24)$ students. Their ages ranged from 18-27 with an average of $21.75 .74 \%$ of the participants were females while $26 \%$ of them were males. The participants all took the English proficiency exam of the university before attending the department, so their language levels were assumed to be similar.

\subsection{Setting}

The study was conducted at a private university in Gaziantep where each student was provided with a laptop. The students had access to Internet at school and the dormitory. Only $14 \%$ of the participants did not have Internet access at their own houses.

In the Department of ELT, some of the courses (skill-based classes, methodology classes, and pedagogy classes) were offered as blended learning classes. The Schoology (www.schoology.com) website was used in the blended courses. Schoology, in its website, was described as an online learning, classroom management, and social networking platform that improves learning through better communication, collaboration, and increased access to curriculum and supplemental content. Through this platform the teachers can create assignments, online quizzes, discussion boards, and can share multimedia files. The students can attend online discussions, send homework, receive online feedback, take exams, and follow their grades and attendance.

\subsection{Data collection instrument}

The instrument used to collect data was adapted from a questionnaire designed by Al-Zumor, Al-Refaai, Badereddin, and Al-Rahman, (2013). The questionnaire was applied to 160 EFL students from the Department of English, Faculty of Languages and Translation, King Khalid University in 2013. The reliability of the questionnaire was measured by using SPSS, Cronbach's Alpha, and the calculated result was 0.79 , which showed that the internal consistency of the scale was high.

Five ELT professionals and a professor of English working at the university under examination evaluated the questionnaire and provided feedback. The questionnaire was then adapted considering the feedback given by the evaluators. The questionnaire was piloted and some questions were either omitted or revised. The reliability of the questionnaire was found to be 0.87 .

The questionnaire consisted of two different parts and 37 questions in total. There were eight questions in the first section that aimed to gather information about the participants' background, level of computer literacy and e-learning experiences. The second section of the questionnaire consisted of 29 Likert-type statements and they were also divided into four different sub-categories. The first eight questions of the second section focused on the relationship between language skills and blended learning. The next nine questions tried to reveal participants' perceptions about the advantages of blended learning while the following seven questions focused on the limitations. The last five questions were related to the participants' suggestions for improving their blended learning experience. 
Yağcı, H., Çınarbaş, H.İ., Hoş, R. (2016). Turkish EFL students' perceptions about blended English courses in a teacher education program. International Journal of Social Sciences and Education Research, 2 (3), 774-784.

\subsection{Data analysis}

Data collected through the questionnaire were analysed via SPSS 21 program. The demographic information was analysed through descriptive statistics. In addition, ANAVO and t-test were conducted to determine the relationships between students' perceptions about blended learning and the demographics.

\section{Findings}

The statistics in this section present the results of t-tests and the analysis of possible variance (ANOVA) in attitudes based on year of study (freshman, sophomore, junior, and senior), students' computer literacy and gender. These variables were expected to guide the students' attitudes regarding language areas benefitting from a blended learning environment, advantages, limitations and suggestions for enhancing the blended learning experience. The question was considered as negative, if the average of a question is lower than mean 3,50.

Regarding language areas, it was found that blended learning provides variable degrees of benefits. As shown in the Table 1, students have a stronger belief that listening and vocabulary were the language areas, which were perceived to be improved through blended learning most.

Table 1. Perceptions of students about blended learning on language skills

\begin{tabular}{|lll|}
\hline & Mean & Std. Dev. \\
Listening & 3.81 & 1.09 \\
Speaking & 3.32 & 1.16 \\
Reading & 3.42 & 1.06 \\
Writing & 3.32 & 1.09 \\
Pronunciation & 3.56 & 1.33 \\
Spelling & 3.55 & 1.23 \\
Grammar & 3.24 & 1.23 \\
Vocabulary & 3.71 & 1.09 \\
\hline
\end{tabular}

However, regarding the reading skills, there was a significant difference between senior group (mean 3.91) and the others (mean 3.42). Sophomores have the most negative attitude (mean 3.05). In addition, grammar is the least developed language area through blended courses. There was a significant difference between genders. Females (mean 3.40) have stronger attitude that writing skills can benefit from blended courses than males. Lastly, in all language areas, senior students showed the most positive attitude (mean 3.78). The other groups showed variance about their attitudes in language areas.

Table 2. Advantages of blended learning

\begin{tabular}{|llc|}
\hline & Mean & Std. Dev. \\
Rapport & 3.12 & 1.03 \\
Multimedia & 3.62 & 1.02 \\
Useful & 3.63 & .94 \\
Pace & 3.58 & 1.02 \\
Computer Literacy & 3.61 & 1.05 \\
Self-Confidence & 3.28 & 1.10 \\
Time Use & 3.28 & 1.06 \\
Feedback & 3.46 & 1.03 \\
Authentic & 3.38 & .92 \\
\hline
\end{tabular}


Yağcı, H., Çınarbaş, H.İ., Hoş, R. (2016). Turkish EFL students' perceptions about blended English courses in a teacher education program. International Journal of Social Sciences and Education Research, 2 (3), 774-784.

When the advantages of the blended learning were analyzed (Table 2), students' attitudes about rapport building between instructor and students were lower than any other advantages (mean 3.12). Male students showed a negative attitude more than females. The students also had the tendency to show a negative attitude towards self-confidence (mean 3.28) and time use (mean 3.28 ) in blended learning courses.

The attitudes about the advantages of blended learning freshmen, junior and senior students show in-group consistency, yet sophomores showed inconsistency in their answers about the advantage category. In addition, it was realized that male students think blended courses provided authentic language learning material (mean 3.81) while females (mean 3.22) think the opposite.

When the limitations of blended learning were analyzed (Table 3), slow Internet connection (mean 4.00) was the major problem in blended courses for all groups. The students showed tendency to prefer printed material than e-materials (mean 3.37). Interestingly, both male (mean 3.20) and female (mean 2.81) students consider that blended courses lead to social isolation, and female students feel more socially isolated than males. In addition, there was a huge difference about the convenience of blended courses among groups and genders (males: 3.62, females: 2.99). Although students' answers indicate that there are different limitations, all groups do not see blended courses difficult to handle (mean 2.82) and hard to use, and the instructions given for blended courses was considered to be easily followed.

Table 3. Limitations of blended learning

\begin{tabular}{|lll|}
\hline & Mean & Std. Dev. \\
Socially Isolated & 2.97 & 1.04 \\
Difficult to Use & 2.82 & 1.01 \\
Connection & 4.00 & .88 \\
Printed Material & 3.37 & 1.11 \\
Plagiarism & 3.31 & 1.07 \\
Instruction & 2.90 & 1.05 \\
Convenient & 3.16 & 1.05 \\
\hline
\end{tabular}

The results obtained from 'suggestions category' (Table 4) indicated that students recommend for improvements of technology at the university. Technical support was highly requested (mean 3.79) and all groups showed consistency about technical support. Additionally, while sophomores (mean 3.16) and juniors (mean 3.37) do not support having more computer labs, freshman (mean 3.63 ) and senior students (mean 3.91) advocate having more computer labs. Interestingly, junior (mean 3.29) and senior students (mean 3.35) suggest that the number of blended courses should be reduced.

Table 4. Suggestions for the improvement of the blended learning experience

\begin{tabular}{|llc|}
\hline & Mean & Std. Dev. \\
Increase Number of Blended Courses & 3.23 & 1.04 \\
Computer Labs & 3.53 & .93 \\
Technical Support & 3.79 & 1.04 \\
Training & 3.64 & .96 \\
Reduce number of Blended Course & 3.09 & 1.10 \\
\hline
\end{tabular}

Additionally, while sophomores (mean 3.64) and juniors (mean 3.91) do not support having 
Yağcı, H., Çınarbaş, H.İ., Hoş, R. (2016). Turkish EFL students' perceptions about blended English courses in a teacher education program. International Journal of Social Sciences and Education Research, 2 (3), 774-784.

more computer labs, freshman (mean 3.12) and senior students (mean 3.32) advocate having more computer labs. Interestingly, junior (mean 3.67) and senior students (mean 3.86) suggest that the number of blended courses should be reduced.

\section{Discussion}

\subsection{Blended learning and English language skills development}

It was found out that the students perceived blended learning to be useful to listening (3.81) and vocabulary (3.71) at most. This finding might result from the fact that the students had to learn a lot of vocabulary to understand and complete their assignments; also they might have been exposed to new vocabulary in the discussions and different multimedia texts. This might have resulted from the fact that they were made to watch movies, listen to podcasts and short movies in different courses.

Grammar (3.24) and speaking (3.32) rated the lowest. As the students can share their opinions through writing only and the Schoology platform does not create a space for speaking, speaking skill was perceived to be less improved as expected. In addition, grammar ranked the lowest. This might have resulted from the fact that there were no direct grammar activities available on Schoology, yet it was not lower than the mean (2.50). It might be due to the feedback provided on the grammar of the students for their written assignments. The students' perceptions about improving their language skills through blended learning did not change according to age, gender, computer literacy, or the year of study.

Previous studies also highlighted the positive effects of blended courses on language skills. The study conducted by Lee and Chong (2007) resulted in a similar way suggesting that online materials helped to improve listening and vocabulary skills. However, according to the results of the study by Adas and Bakir (2013) blended learning improved students' writing, spelling and grammar skills, which are accepted as the least improved skills by the students in this study. If Schoology had contained direct grammar activities, this situation would have changed and the results would have been similar regarding grammar skills.

\subsection{Advantages and disadvantages of e-learning}

Blended courses provide authentic language material because audio-visual language learning materials can be easily presented in Schoology. Students see blended courses as useful because they can work according to their pace and they can improve their computer skills. However, rapport building between instructors and students were found to be low (3.12). Possible reasons could be no direct human interaction in online platforms or the less hours of meeting with the instructors. In addition, female students feel more socially isolated in blended courses since females want to be socially integrated. In blended courses, students have problems with time management, because blended courses may require having computer skills and good technical support such as fast Internet connection, or computer labs.

Although Heinze and Procter (2004) states the superiority of blended learning over e-learning in terms of socializing, the results of their study show that sometimes even blended learning may not create enough opportunity to communicate and socialize. These results show parallelism with the current study as students; especially females expressed that they feel isolated in the blended courses. 
Yağcı, H., Çınarbaş, H.İ., Hoş, R. (2016). Turkish EFL students' perceptions about blended English courses in a teacher education program. International Journal of Social Sciences and Education Research, 2 (3), 774-784.

\subsection{Limitations and problems}

Slow Internet connection was stated as the major problem for students in blended courses because it can be difficult to handle instructions given in blended courses with slow Internet connection. Also Hisham, CheSu, and Hassan Abu Bakar (2006) express in their study that instructions given for online tasks should be clear enough otherwise learners might feel lost and have difficulties in getting used to blended learning. The results of another study by Chen and Jones (2007) also support this idea because in this study the students who participated in the traditional class were found happier about the clear instructions compared to the students in blended learning class.

Kistow (2011) has found that the students enjoyed taking part in blended courses and as these courses provide a flexible atmosphere the same situation was expected for the current study. Surprisingly, students preferred more face-to-face teaching. As students actively participate different forms of online activities, they want to have more human interaction and connection in their courses. Additionally, senior students preferred printed material as expected because they are technology immigrants compared to the other groups.

\subsection{Students' suggestions}

Suggestions students provided possibly differed according to their personal preference and background. Senior and junior students suggested reducing the number of blended courses. The workload increases due to the blended courses and this can influence students' suggestions. In order to have a good quality of blended course, technical support and fast Internet connection is strongly recommended.

\section{Conclusion}

Due to advances in technology and new trends in education, blended learning is getting more and more common. Although it is a hot debate topic, it is hard to deny the fact that blended learning is beneficial, as it combines the face-to-face education with the online education. The current study explored the perceptions of Turkish ELT students about blended learning on improving language skills and tried to find out the advantages and limitations of blended learning. It also asked for the suggestions of the students to improve this experience.

The study was conducted at a private university in Gaziantep in Southeast Turkey. The participants $(\mathrm{N}=101)$ were selected through stratified random sampling. The data was collected through a questionnaire consisting of four subcategories: skills improved, advantages, limitations, and suggestions.

The blended learning was perceived to be effective in improving language skills; especially, vocabulary and listening. The perceptions of the students did not vary according to their gender or year of study. On one hand, the main advantage of the blended learning was perceived to be the use of multimedia tools, and on the other hand, the connection problem was the top limitation selected by the students. Finally, the students suggested more technical help and training.

Overall, the results showed consistency with previous research conducted to find out perceptions of students about blended learning. 
Yağcı, H., Çınarbaş, H.İ., Hoş, R. (2016). Turkish EFL students' perceptions about blended English courses in a teacher education program. International Journal of Social Sciences and Education Research, 2 (3), 774-784.

\section{Limitations}

Whilst the findings of the study could be applied in most instances, there were some limitations. The sample of the study was limited to one department (ELT) and a single university in Turkey. Moreover, $26 \%$ of the participants were males while the majority were females.

In the study, Likert scale was used. With this scale, it is difficult to claim that the interval between "strongly agree" and "agree" is equal to interval between "agree" and "undecided" (Kothari, 2004). The difference between these intervals might be slight for a participant while it might be great for the others. Another limitation of the study is its dependence on the quantitative data. The qualitative data might clarify the perceptions of the students and might be useful in understanding the difference among the students at different years of study.

\section{Implications}

This study is significant in contributing to the current literature on the perceptions of students about blended learning in improving language skills. This study was conducted with a limited number of students at one university; future research might be conducted at different universities with a larger sample size. There was no significant difference among the perceptions of the students about blended learning and their gender, age and year of study. This might be investigated for better understanding through qualitative research. Interviews or focus groups might be conducted to further explore the perceptions of the learners.

The students should be trained more about blended learning and their computer literacy should be increased for better improvement in different language skills. The Internet and technical problems can affect the quality of blended learning; therefore, technical support should be available for students.

\section{References}

Abrahamson, C. E. (1998). Issues in interactive communication in distance education. College Student Journal, 32(1), $33-43$.

Adas, D., \& Bakir, A. (2013). Writing difficulties and new solutions: Blended learning as an approach to improving writing abilities. International Journal of Humanities and Social Science, 3(9), 254-266.

Akkoyunlu, B., \& Soylu, M. Y. (2008). A study of student's perceptions in a blended learning environment based on different learning styles. Educational Technology \& Society, 11(1), 183-193.

Al-Zumor, A. W. Q., Al-Refaai, I. K., Badereddin, E. A., \& Al-Rahman, F. H. A. (2013). EFL Students' Perceptions of a Blended Learning Environment: Advantages, Limitations and Suggestions for Improvement. English Language Teaching, 6(10), 95-110.

Allan, B. (2007). Blended learning: Tools for teaching and training. London: Facet.

Ayres, R. (2002). Learner attitudes towards the use of CALL. Computer Assisted Language Learning, $15(3), 241-249$.

Bonk, C., \& Graham, C. (2006). The handbook of blended learning: Global perspectives, local designs. San Francisco: Pfeiffer.

Brew, L. S. (2008). The role of student feedback in evaluating and revising a blended learning course. Internet and Higher Education, 11, 98-105.

Bueno-Alastuey, M. C., \& López-Pérez, M. V. (2014). Evaluation of a blended learning language course: students' perceptions of appropriateness for the development of skills and language areas. Computer Assisted Language Learning, 27(6), 509-527. 
Yağcı, H., Çınarbaş, H.İ., Hoş, R. (2016). Turkish EFL students’ perceptions about blended English courses in a teacher education program. International Journal of Social Sciences and Education Research, 2 (3), 774-784.

Byrne, T. (2007). Marrying two existing software packages into an efficient online tutoring tool. Computer Assisted Language Learning, 20(5), 459-468.

Chen, C.C., \& Jones, K.T. (2007). Blended Learning vs. Traditional Classroom Settings: Assessing Effectiveness and Student Perceptions in an MBA Accounting Course. The Journal of Educators Online, 4(1).

Cohen, L., Manion, L. and Morrison, K. (2007). Research Methods in Education (6 ${ }^{\text {th }}$ Ed.). London: Routledge.

Deghaidy, H. E., \& Nouby, A. (2008). Effectiveness of a blended e-learning cooperative approach in an Egyptian teacher education program. Computers \& Education, 51, 988-1006.

Delialioğlu, O., \& Y1ldırım, Z. (2007). Students’ Perceptions on Effective Dimensions of Interactive Learning in a Blended Learning Environment. Educational Technology \& Society, 10(2), 133-146.

Dörnyei, Z. (2007). Research methods in applied linguistics. Oxford: Oxford University.

Hara, N., \& Kling, R. (2000). Students' distress with a web-based distance education course: An ethnographic study of participants' experiences. Information, Communication and Society, 3(4), 557-579.

Heinich, R., Molenda, M., Russell, J. D., \& Smaldino, S. E. (2002). Instructional media and technologies for learning $\left(7^{\text {th }}\right.$ ed.). Upper Saddle River, NJ: Merrill Prentice Hall.

Heinze, A., \& Procter, C. (2004). Reflections on the use of blended learning. Education in a Changing Environment Conference Proceedings, University of Salford. Salford: Education Development Unit.

Hisham D., Che Su M., \& Hasan A. B. (2006). Moving forward with blended learning (BL) as a pedagogical alternative to traditional classroom learning. Malaysian Online Journal of Instructional Technology (MOJIT), 3(1), 11-18.

Kistow, B. (2011). Blended learning in higher education: A study of a graduate school of business, Trinidad and Tobago. Caribbean Teaching Scholar, 1(2), 115-128.

Kothari, C. R. (2004). Research Methodology: Methods and Techniques (2 ${ }^{\text {nd }}$ Ed.). New Delhi: New Age International limited.

Lee, K. C., \& Chong, P. M. (2007). An observational study on blended learning for Japanese language studies. In Fong, J., \& Wang, F. L. (Eds.), Blended learning (pp. 88-100). Edinburgh, Scotland: Pearson.

Lim, D. H., Morris, M. L., \& Kupritz, V. W. (2006). Online vs. blended learning: differences in instructional outcomes and learner satisfaction. Online Submission, 39(1), 809-816.

Marino, T. A. (2000). Learning Online: A view from both sides. The National Teaching \& Learning Forum, $9(4), 4-6$.

Moore, M. G., \& Kearsley G. (2012). Distance education: A systems view of online learning. Technologies and media ( $3^{\text {rd }}$ ed.). Belmont, CA: Wadsworth.

Osguthorpe, R. T., \& Graham, C. R. (2003). Blended learning environments: Definitions anddirections. The Quarterly Review of Distance Education, 4(3), 227-233.

Pallof, R., \& Pratt, K. (2003). The Virtual Student: A Profile and Guide to Working with Online Learners. San Francisco, CA: Josey-Bass Publishers.

Procter, C. (2003). Blended Learning in Practice, in Inaugural Education in a Changing Environment Conference. University of Salford, Salford.

Redmond, P. (2011). From face-to-face teaching to online teaching: Pedagogical transitions. In G. Williams, P. Statham, N. Brown \& B. Cleland (Eds.), Changing Demands, Changing Directions.Proceedings ascilite Hobart 2011. (pp.1050-1060).

Rogers, P. L. (2001). Traditions to Transformations: The Forced Evolution of Higher Education, in Educational Technology Review, 9(1). 
Yağcı, H., Çınarbaş, H.İ., Hoş, R. (2016). Turkish EFL students' perceptions about blended English courses in a teacher education program. International Journal of Social Sciences and Education Research, 2 (3), 774-784.

Rooney, J. E. (2003). Blending learning opportunities to enhance educational programming and meetings. Association Managment, 55(5), 26-32.

Rovai, A., \& Jordan, H. (2004). Blended learning and sense of community: a comparative analysis with traditional and fully online graduate courses. The International Review of Research in Open and Distance Learning, 5(2).

Sarason, Y., \& Banbury, C. (2004). Active learning facilitated by using a game-show format or who doesn't.Journal of Management Education, 28(4), 509-518.

Smart, K. L., \& Cappel, J. J. (2006). Students' perceptions of online learning: A comparative study. Journal of Information Technology Education, 5.

Stewart, J. (2002). A blended e-learning approach to intercultural training. Industrial and Commercial Training, 34(7), 269-271. 